\title{
Iniciativas para a implantação do Floram
}

\author{
JACQUES MARCOVITCH
}

$\mathrm{T}$

EM CRESCIDO NOS ÚLTIMOS ANOS a consciência coletiva quanto a importância da cobertura vegetal para a sobrevivência da humanidade. A influência das florestas sobre o clima já é de conhecimento de amplas camadas da população. Simultaneamente, as dificuldades enfrentadas pelos Estados têm inibido a adoção de medidas propostas na reunião realizada no Rio, em 1992, que abordou o tema. A escassez de recursos públicos inibe as tentativas de diversos países na busca de novas formas de viabilizar a proteção das florestas. O projeto Floram é apresentado como uma proposta de política publica propondo a conciliação de objetivos múltiplos.

A estabilidade monetária, assim como as reservas financeiras acumuladas pelo Brasil na atualidade, são condições prévias para a expansão do horizonte de tempo para investimentos em projetos de longo prazo de maturação. Enquanto tais pré-condições perdurarem, existem probabilidades de que empreendedores viabilizem o projeto.

Com a elevação do preço da celulose no mercado mundial, o faturamento das 20 maiores empresas sediadas no Brasil, em 1994, alcançou a expressiva cifra de US\$ 6,4 bilhões. Em 1995, uma das empresas do setor de reprografia, usando eletrônica avançada, obteve um faturamento de US\$ 1,4 bilhão, valor que permite perceber os expressivos volumes de recursos constitutivos da cadeia produtiva ou filiere tendo sua origem na celulose como matéria-prima.

A edição da ISO 14000 e a crescente consciência ambiental têm induzido as empresas e os governos a prestarem especial atenção à questão florestal, num país onde mais da metade da madeira consumida é oriunda de florestas nativas.

Estes fatores propulsores que contribuiriam para a implantação de algumas iniciativas Floram pelo Brasil, apesar de sua relevância, têm uma influência ainda tímida. O baixo valor atribuído aos recursos naturais, a drástica redução do preço dos energéticos após a Guerra do Golfo e a elevada lucratividade dos investimentos especulativos afastam os recursos financeiros dos projetos de longa maturação, de rentabilidade moderada, mas de elevada segurança.

A divulgação do Floram no Brasil e, mais recentemente no exterior, tem 
inspirado algumas empresas e governos a elaborarem seus planos à luz das diretrizes expostas no projeto. A política florestal adotada pelo governo do estado de Minas Gerais, por exemplo, inclui uma iniciativa de florestamento de $450 \mathrm{mil}$ hectares e adota os princípios do Floram.

Como assegurar, então, a implantação do projeto diante dos fatores propulsores e inibidores já expostos? A heterogeneidade das condições ambientais, econômicas e sociais no Brasil sugere a priorização de algumas medidas de estímulo para a sua implementação.

Cabe, inicialmente, analisar as políticas de financiamento de longo prazo no Brasil com a participação das principais empresas, associações e, em especial, do Banco Nacional de Desenvolvimento Econômico e Social para debater as prioridades propostas e as formas de implantação de projetos de ciclo longo.

É oportuna a proposição de uma política florestal brasileira e de um projeto de le $i$ a ser debatido pelo Legislativo, pelo Executivo e pela sociedade em geral. A discussão deste projeto, que pode se iniciar no âmbito de alguns estados, deverá enfatizar a importância da conciliação dos componentes econômico, ecológico e social. Deverá também estabelecer uma base de entendimento para as empresas interessadas em investir no setor.

A política florestal deverá ainda explicitar a vontade da sociedade com relação à cobertura vegetal do país. Nela deverão constar mecanismos diretos de incentivos e estímulos, isto é, medidas fiscais e instrumentos regulatórios. As medidas fiscais incluiriam, por exemplo, impostos, depreciação e isenção de taxas. Dos mecanismos regulatórios deveriam constar, entre outros, colegiados responsáveis pela implantação da política com poder de decisão sobre seguro, infra-estrutura de apoio, comércio internacional de madeiras. Tais mecanismos poderão ser complementados por ações de apoio nos campos científico, educacional, cultural e no sistema de inovação tecnológica.

Com uma política florestal explicitada e indicadores ambientais confiáveis haverá maior facilidade na obtenção de recursos externos, quer sob a forma de doações, quer de empréstimos de longo prazo.

Cada vez mais merecem destaque iniciativas e ações afirmativas que conseguiram conciliar com êxito a elevação da competitividade, a redução das discrepâncias sociais e a preservação do meio-ambiente. O reconhecimento da excelência em florestamento e meio-ambiente constituiria uma das formas de evidenciar a filosofia do Floram, em casos práticos a servirem de guia àqueles que desejam visualizar formas de implantação do Floram. A escolha e a disseminação de indicadores ambientais permitem o acompanhamento da involução da cobertura florestal brasileira e constituem elementos para a conscientização quanto à 
prioridade do projeto. Os princípios do Floram podem ser disseminados junto ao sistema educacional, através da elaboração de material didático em forma de fascículos, dirigido às escolas de primeiro e segundo graus. Tais fascículos, produzidos com a participação de licenciandos em educação, contribuiriam para a formação das gerações que estão por assumir a responsabilidade pelos destinos do país.

A implantação das propostas referidas poderá ser realizada através de:

- rede de pessoas que têm atuado no Floram no âmbito do Instituto de Estudos Avançados da USP.

- Os compromissos a serem assumidos, no entanto, exigem a constituição de uma associação, reunindo pessoas que se coloquem a serviço das idéias do Floram.

- Outra alternativa, mais ousada, é constituir um patrimônio a serviço de um ideário através da instituição de uma fundação.

Estas propostas - rede, associação ou fundação - devem ser avaliadas com base nos objetivos almejados e no ritmo das atividades a serem realizadas.

A rede poderia ser institucionalizada com a indicação de correspondentes nos vários estados ou instituições prioritárias para a implantação do projeto. Quanto à associação, ela seria dirigida por um conselho técnico-científico-administrativo e uma coordenação executiva. $O$ conselho deveria indicar grupos-tarefas para tratar de assuntos específicos. A filiação seria voluntária, por candidatura ou indicação, tendo por critério de aceitação a disposição dos interessados em colaborar na implantação do projeto e em sua atuação no setor. Com relação à fundação, seus instituidores deveriam alocar um patrimônio inicial e, em seguida, eleger um conselho curador. O conselho, por sua vez, elegeria uma diretoria que se responsabilizasse pela execução das atividades da fundação e pela implantação dos seus projetos.

Nas três alternativas - rede, associação ou fundação -, a missão deverá ser clara, os objetivos mensuráveis, os recursos humanos motivados, os recursos financeiros compatíveis e os resultados sujeitos a acompanhamento e avaliação externos.

Linhas de financiamento de longo prazo, política florestal, reconhecimento da excelência, disseminação de indicadores e sensibilização dos jovens constituem a agenda mínima de iniciativas como o Projeto Floram, que contribuem para o desenvolvimento sustentado. 
Referências bibliográficas

ISO 14000. Environmental management systems. Environmental auditing, audit procedures, qualification criterias for environmental auditors, environmental labeling. [Local, editora, data?]

JORGE, Maurício Mendonça. Desenvolvimento e competitividade do setor de papel e celulose no Brasil. Cepal - Comissão Econômica para América Latina e Caribe, 1995.

NILSSON, Gunnar \& WESTMAN, Mattias. Project Floram - forestry with global implications (a thesis in international business). Stockholm, Handelshögskolan, Stockholm School of Economics, 1993.

Jacques Marcovitch é pró-reitor de Cultura e Extensão da Universidade de São Paulo, coordenador da Área de Assuntos Internacionais do Instituto de Estudos Avançados da usP e professor titular da Faculdade de Economia e Administração da UsP. 